\title{
PENGARUH PENGETAHUAN IBU MENYUSUI TERHADAP KECUKUPAN ASI DI WILAYAH KELURAHAN MARGADANA
}

\author{
Meyliya Qudriani ${ }^{1}$, Evi Zulfiana ${ }^{2}$, Seventina Nurul Hidayah ${ }^{3}$ \\ e-mail: meyliya.qudriani@gmail.com \\ ${ }^{1,2,3)}$ DIII Kebidanan Politeknik Harapan Bersama \\ Jalan Mataram No 9 Kota Tegal 52142, Indonesia Telp (0283) 352000
}

\begin{abstract}
Abstrak
Air Susu Ibu merupakan makanan yang tepat untuk bayi terutama pada bulan-bulan pertama, karena mengandung zat gizi yang diperlukan bayi untuk membangun dan menyediakan energi. Kandungan zat gizinya yang lengkap, sehingga mudah dicerna dan diserap secara efisien. Data yang didapatkan dari Puskesmas margadana tahun 2016 terdapat 215 bayi. Dimana dari 215 bayi hanya 59.1\% (127 bayi) yang mendapatkan ASI Eksklusif. 18.1\% (39 bayi) masih dalam tahap pemberian ASI Eksklusif dan 22,8\% (49 bayi) tidak mendapat Asi Eksklusif. Capaian tersebut sangat jauh dari target nasional 85\%. Tujuan penelitian untuk mengetahui pengaruh pengetahuan ibu menyusui terhadap kecukupan ASI di Wilayah Kelurahan Margadana tahun 2017. Penelitian ini menggunakan metode pre-eksperimen dengan rancangan penelitian one group pretest-posttest desain yang dilakukan di wilayah kerja puskesmas margadana dengan populasi ibu yang mempunyai bayi berusia dibawah 1 bulan sebanyak 22 responden. Dengan membagikan kuesioner kepada responden dan dilakukan analisis data dengan analisis uji beda. Hasil penelitian rata-rata tingkat pengetahuan responden sebelum mendapatkan pendidikan kesehatan tentang kecukupan ASI adalah 6,27 dan setelah mendapatkan pendidikan kesehatan tentang kecukupan ASI mengalami peningkatan yaitu 9,59. Sedangkan setelah dilakukan analisis menggunakan uji beda didapatkan nilai pvalue 0,000 , lebih kecil dari 0,05 maka dapat disimpulkan bahwa terdapat perbedaan yang signifikan antara pengetahuan ibu menyusui sebelum dan sesudah mendapatkan pendidikan kesehatan.
\end{abstract}

Kata kunci: Ibu Menyusui, Kecukupan ASI, Nifas

\section{Pendahuluan}

Air Susu Ibu merupakan makanan yang tepat untuk bayi terutama pada bulan-bulan pertama, karena mengandung zat gizi yang diperlukan bayi untuk membangun dan menyediakan energi. Kandungan zat gizinya yang lengkap, sehingga mudah dicerna dan diserap secara efisien. Selain itu, ASI juga mengandung immunoglobulin untuk kekebalan tubuh bayi. ASI juga menunjang kecerdasan dan pelindung bagi kesehatan anak. $^{[1]}$

Dilihat dari fenomena yang terjadi pada masyarakat bahwa yang dapat memberikan ASI eksklusif selama 6 bulan pertama kelahiran bayi hanya sekitar 5\%, padahal $98 \%$ ibu-ibu tersebut menyusui bayinya. Dari fenomena tersebut juga didapatkan bahwa $37,9 \%$ ibu-ibu tidak pernah mendengar informasi tentang ASI sedangkan $70,4 \%$ ibu-ibu tidak pernah mendengar informasi tentang ASI eksklusif. ${ }^{[2]}$

Di indonesia, cakupan capaian ASI Eksklusif masih cukup rendah dimana pada tahun 2013 capaian sekitar 38\%. Cakupan ASI Eksklusif di Jawa Tengah Mengalami Penurunan dimana pada tahun 2011 sebesar45.18\% dan tahun 2012 menurun menjadi $25.6 \%$. kota Tegal merupakan salah satu yang memiliki cakupan Asi Eksklusif yang rendah $23,8 \% .{ }^{[3]}$ Data yang didapatkan dari Puskesmas margadana tahun 2016 terdapat 215 bayi. Dimana dari 215 bayi hanya $59.1 \%$ (127 bayi) yang mendapatkan ASI Eksklusif. 18.1\% (39 bayi) masih dalam tahap pemberian ASI Eksklusif dan $22,8 \%$ (49 bayi) tidak mendapat Asi Eksklusif. Capaian tersebut sangat jauh dari target nasional $85 \%$.

Penyebab kegagalan pemberian ASI Eksklusif salah satunya adalah pengetahuan ibu. Faktor pengetahuan ibu maupun keluarga sangat mendukung proses pemberian air susu ibu. Banyak keluhan ibu menyusui bahwa anaknya tidak sabaran, ibu mengatakan air susunya tidak keluar, anaknya tidak mau menyusu, dan lain sebagainya. Hal ini dapat terjadi dan sering 
terjadi di masyarakat, begitu pula ibu menyusui yang juga harus meninggalkan rumah untuk bekerja. Sebenarnya apa yang dikeluhkan dapat dicegah, apabila mengetahui penyebabnya. ${ }^{[4]}$

Pendidikan seorang ibu yang rendah memungkinkan ia lambat dalam mengadopsi pengetahuan baru, khususnya tentang hal-hal yang berhubungan dengan pola pemberian ASI. Masalah pemberian ASI terkait dengan masih rendahnya pemahaman ibu, keluarga dan masyarakat tentang ASI. Tidak sedikit ibu yang masih membuang kolostrum karena dianggap kotor sehingga perlu dibuang. Selain itu, kebiasaan memberikan makanan dan atau minuman secara dini pada sebagian masyarakat juga menjadi pemicu dari kurang keberhasilan pemberian ASI eksklusif. Ditambah lagi dengan kurangnya rasa percaya diri pada sebagian ibu untuk dapat menyusui bayinya. Hal ini mendorong ibu untuk lebih mudah menghentikan pemberian ASI dan menggantinya dengan susu formula. ${ }^{[5]}$

Dari data yang didapatkan oleh peneliti, maka peneliti ingin meneliti tentang Pengaruh Pengetahuan Ibu Menyusui Terhadap Kecukupan ASI di Wilayah Kelurahan Margadana.

\section{Metode Penelitian}

Penelitian ini menggunakan metode pre-eksperimen dengan rancangan penelitian one group pretest-posttest desain yang dilakukan di wilayah kerja puskesmas margadana dengan populasi ibu yang mempunyai bayi berusia dibawah 1 bulan sebanyak 22 responden.

Penelitian dilakukan dengan membagikan kuesioner kepada responden dan dilakukan analisis data dengan analisis uji beda. $^{[6]}$

\section{Hasil dan Pembahasan}

Hasil penenilitian disajikan dalam dua analisis yaitu analisis univariat dan analisis bivariat yang dilakukan dengan analisis uji beda yang bertujuan untuk mengetahui perbedaan pengetahuan ibu menyusui sebelum dan sesudah diberikan penyuluhan tentang kecukupan ASI. a. Karakteristik responden tingkat pendidikan

Tabel 1. Karakteristik responden berdasarkan tingkat pendidikan

\begin{tabular}{llll}
\hline No & Pendidikan & F & \% \\
\hline 1 & Dasar & 4 & 18,2 \\
2 & Menengah & 16 & 72,8 \\
3 & Tinggi & 2 & 9 \\
\hline & TOTAL & 22 & 100
\end{tabular}

Berdasarkan tabel diatas menunjukkan bahwa sebagian responden mempunyai tingkat pendidikan Menengah (SMP/SMA) yang berjumlah 16 responden $(72,8 \%)$.

Faktor yang dapat mempengaruhi kurangnya pengetahuan ibu tentang kecukupan ASI antara lain yaitu kurang jelasnya informasi yang diberikan oleh tenaga kesehatan kepada ibu, kurangnya kemampuan ibu dalam memahami informasi yang diberikan kepada ibu dikarenakan tingkat pendidikan ibu yang masih rendah. Makin tinggi pendidikan seseorang akan semakin mudah untuk menerima informasi sehingga akan lebih banyak pengetahuan yang didapatkan. ${ }^{[7]}$

Tingkat pendidikan pada responden penelitian ini sebagian besar dengan tingkat pendidikan menengah yaitu SMP dan SMA, hal ini yang mempengaruhi pengetahuan ibu dimana pengetahuan ibu tentang kecukupan ASI masih rendah yang dapat dilihat dari pengetahuan ibu sebelum mendapatkan penyuluhan masih rendah. $^{[8]}$

b. Karakteristik responden berdasarkan pekerjaan

Tabel 2. Karakteristik responden berdasarkan pekerjaan

\begin{tabular}{llll}
\hline No & Pekerjaan & F & $\%$ \\
\hline 1 & Tidak Bekerja & 16 & 72,7 \\
2 & Bekerja & 6 & 27,3 \\
\hline & TOTAL & 22 & 100 \\
\hline
\end{tabular}

Berdasarkan tabel diatas menunjukkan bahwa sebagian responden tidak bekerja yaitu 16 responden $(72,7 \%)$. 
Pekerjaan adalah kegiatan yang harus dilakukan untuk menunjang kehidupan dan kebutuhan keluarga. Dengan bekerja juga diperkirakan dapat mempengaruhi pengetahuan ibu. Kesibukan dalam bekerja mempengaruhi ibu untuk tidak dapat mengikuti kegiatan penyuluhan atau pendidikan kesehatan yang mampu menambah pengetahuan ibu khususnya tentang kesehatan ibu menyusui. Dalam penelitian ini responden yang tidak bekerja lebih aktif mengikuti posyandu sehingga pengetahuan tentang kecukupan ASI lebih baik dibandingkan dengan responden yang bekerja. Hal ini sesuai dengan penelitian alfiah, $\mathrm{R}$ dan friska, $R$ (2016) tentang pengetahuanibu hamil tentang kecukupan ASI yang mengatakan dalam penelitiannya bahwa ibu yang sibuk bekerja diluar rumah akan mempunyai waktu yang lebih sedikit dibandingkan dengan ibu yang tidak bekerja mempunyai peluang waktu yang lebih banyak untuk keluarga dan mengikuti kegiatan yang ada seperti penyuluhan kesehatan untuk lebih meningkatkan pengetahuannya.

c. Pengetahuan responden sebelum dan sesudah diberikan pendidikan kesehatan tentang kecukupan ASI

Tabel 3. Pengetahuan responden sebelum dan sesudah diberikan pendidikan kesehatan tentang kecukupan ASI

Paired Samples Statistic

\begin{tabular}{|c|c|c|c|}
\hline & Mean & $\mathrm{N}$ & $\begin{array}{l}\text { Std. } \\
\text { Eror }\end{array}$ \\
\hline $\begin{array}{l}\text { Sebelum } \\
\text { Penyuluhan }\end{array}$ & 6,27 & 22 & 0,589 \\
\hline $\begin{array}{l}\text { Sesudah } \\
\text { Penyuluhan }\end{array}$ & 9,59 & 22 & 0,382 \\
\hline
\end{tabular}

Berdasarkan tabel diatas menunjukkan bahwa rata-rata tingkat pengetahuan responden sebelum mendapatkan pendidikan kesehatan tentang kecukupan ASI adalah 6,27 dan setelah mendapatkan pendidikan kesehatan tentang kecukupan ASI mengalami peningkatan yaitu 9,59 .

Pengetahuan responden yang digali dalam penelitian ini diantaranya yaitu tentang manfaat ASI, Kandungan ASI, pemberian ASI selama 6 bulan, pemberian makanan pendamping ASI, Gizi ibu menyusui, cara memperbanyak ASI, tanda bayi cukup ASI.

Pengetahuan merupakan hasil dari tahu dan terjadi setelah orang melakukan penginderaaan terhadap suatu objek tertentu. Pengetahuan merupakan faktor yang sangat penting dalam membentuk tindakan seseorang. Tingkat pengetahuan seseorang juga dipengaruhi oleh beberapa faktor diantara adalah tingkat pendidikan, dengan tingkat pendidikan yang tinggi maka diharapkan pengetahuan seseorang akan semakin baik dan akan meningkatkan perilaku kesehatan yang lebih baik.

Pendidikan kesehatan merupakan proses perubahan yang bertujuan untuk merubah individu, kelompok dan masyarakat menuju hal-hal yang positif secara terencana melalui proses belajar. Dengan memberikan pendidikan kesehatan yang terus menerus diharapkan dapat menghasilkan perubahan dan peningkatan pengetahuan terhadap individu. Perubahan tersebut mencakup perubahan emosi, pengetahuan, pikiran dan keinginan, tindakan nyata dari individu, kelompok, dan masyarakat.

Dalam penelitian ini pengetahuan responden mengalami peningkatan setelah dilakukan penyuluhan atau pemberian pendidikan kesehatan tentang kecukupan ASI. Sehingga dengan adanya pemberian pendidikan kesehatan pada ibu menyusui dapat menambah pegetahuan ibu yang diharapkan dapat merubah perilaku ibu dalam meningkatkan pemberian ASI pada bayinya. Penelitian ini sejalan dengan penelitian Faridah, S (2017), yang menggemukkan bahwa terdapat peningkatan pengetahuan ibu menyusui yang lebih baik setelah diberikan penyuluhan tentang teknik menyusui.

d. Perbedaan tingkat pengetahuan ibu menyusui sebelum dan sesudah mendapatkan pendidikan kesehatan kecukupan ASI 
Tabel 4. Perbedaan tingkat pengetahuan ibu menyusui sebelum dan sesudah mendapatkan pendidikan dan sesudah mendapatkan pendidikan kesehatan kecukupan ASI

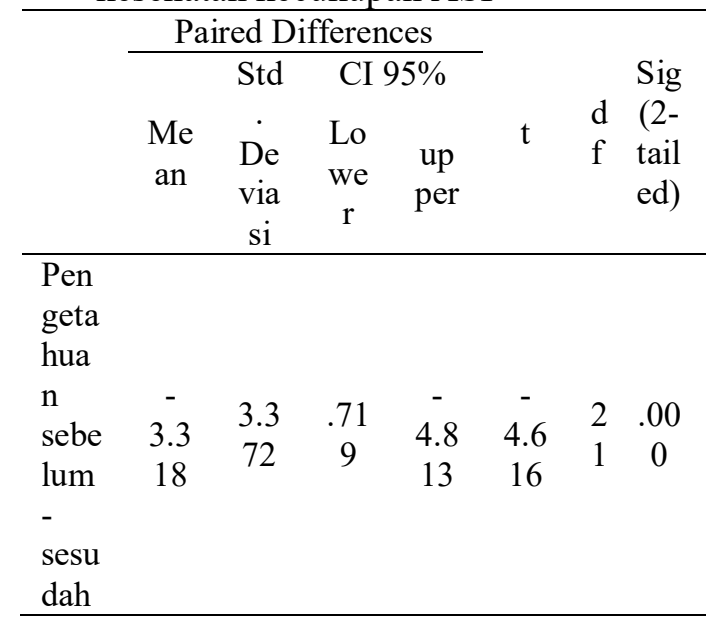

Dari tabel diatas yang didapatkan dari hasil uji beda menunjukkan bahwa nilai $\mathrm{p}$ value $<0,001$ lebih kecil dari 0,05 yang artinya terdapat perbedaan yang signifikan antara pengetahuan ibu menyusui sebelum dan sesudah mendapatkan penyuluhan.

Pengetahuan diperoleh melalui informasi yaitu kenyataan (fakta) dengan melihat, mendengar sendiri, serta melalui alat komunikasi. ${ }^{[10]}$ Dengan adanya informasi yang disampaikan tentang kecukupan ASI kepada ibu menyusui dapat mempengaruhi pengetahuannya. Semakin banyak seseorang terpapar informasi maka akan semakin bertambah pula pengetahuan yang akan didapatkannya.

Salah satu informasi yang diberikan untuk menambah pengetahuan akan kesehatan yaitu dengan memberikan pendidikan kesehatan kepada masyarakat yang tujuannya akan merubah perilaku kesehatan kepada masyarakat tersebut. Pendidikan kesehatan adalah aplikasi atau penerapan pendidikan dalam bidang kesehatan untuk meningkatkan pengetahuan, sikap, praktek baik individu, kelompok atau masyarakat dalam memelihara dan meningkatkan kesehatan mereka sendiri. ${ }^{[10]}$ Sehingga dengan adanya pendidikan kesehatan yang diberikan kepada ibu menyusui akan menambah pengetahuannya.

ASI merupakan makanan yang telah disiapkan untuk calon bayi saat mengalami kehamilan. Produksi ASI sangat dipengaruhi oleh makanan yang dikonsumsi ibu. Dengan makan makanan yang mengandung gizi cukup maka akan mempengaruhi peningkatan produksi ASI. ${ }^{[9]}$ Kecukupan ASI pada bayi dapat dilihat dari kenaikan berat badan bayi yaitu kurang lebih berat badan bayi mengalami kenaikan 500 gram/bulan atau $125 \mathrm{gram} / \mathrm{minggu}$.

Hasil dari penelitian ini menunjukkan bahwa pengetahuan ibu menyusui setelah diberikan pendidikan kesehatan tentang kecukupan ASI mengalami perubahan yang lebih baik dibandingkan sebelum diberikan pendidikan kesehatan tentang kecukupan ASI sebagaimana yang telah dijelaskan bahwa penyampaian informasi melalui pendidikan kesehatan akan mempengaruhi pengetahuan seseorang. Penelitian ini sejalan dengan penelitian Faridah, S (2017) yang menyatakan terdapat peningkatan pengetahuan ibu menyusui sebelum dan sesudah penyuluhan di RSUD Dr. Harjono Ponorogo. ${ }^{[1]}$

\section{Kesimpulan}

Hasil penelitian menunjukkan bahwa:

a. Sebagian responden mempunyai tingkat pendidikan Menengah (SMP/SMA) yang berjumlah 16 responden $(72,8 \%)$.

b. Sebagian responden tidak bekerja yaitu 16 responden $(72,7 \%)$.

c. Rata-rata tingkat pengetahuan responden sebelum mendapatkan pendidikan kesehatan tentang kecukupan ASI adalah 6,27.

d. Rata-rata tingkat pengetahuan responden setelah mendapatkan pendidikan kesehatan tentang kecukupan ASI mengalami peningkatan yaitu 9,59.

e. Uji beda didapatkan nilai pvalue $<0,001$, lebih kecil dari 0,05 maka dapat disimpulkan bahwa terdapat perbedaan yang signifikan antara pengetahuan ibu menyusui sebelum 
dan sesudah mendapatkan pendidikan kesehatan.

\section{Daftar Pustaka}

[1] Soetjiningsih. 2008. ASI Petunjuk Untuk Tenaga Kesehatan. Jakarta: EGC

[2] Roesli, U. 2009. Mengenal ASI Eksklusif. Jakarta: PT. Pustaka Pembangunan Swadaya Nusantara

[3] Depkes RI. 2004. Profil Depkes RI. Jakarta: Depkes RI

[4] Suherni. 2009. Perawatan Masa Nifas. Yogyakarta

[5] Sulistyawati, A. 2010. Buku Ajar Asuhan Kebidanan Pada Ibu Nifas. Yogyakarta

[6] Arikunto. 2006. Prosedur Penelitian. Jakarta: Rineka Cipta

[7] Notoatmodjo, S. 2005. Metodologi Penelitian Kesehatan. Jakarta: Rineka Cipta

[8] Nursalam. 2008. Konsep dan Penerapan Metodologi Penelitian Ilmu Keperawatan. Jakarta : Salemba Medika

[9] Heryani, R. 2012. Asuhan Kebidanan Ibu Nifas dan Menyusui. Jakarta: TIM

[10] Notoatmodjo S, 2009. Pendidikan dan Perilaku Manusia. Jakarta: PT Rieneka Cipta

[11] Faridah, S. 2017. Perbedaan Pengetahuan Teknik Menyusui Sebelum dan Sesudah Penyuluhan. Indonesian Journal for Healh Sciences (IJHS). Vol I. No. 1. Maret 2017. Fakultas Ilmu Kesehatan Universitas Muhammadiah Ponor. 